\title{
From Perspective to Practice: Gauging the Awareness and Integration Level of ICT in Teaching Process at Secondary Level in District Shaheed Benazirabad, Pakistan
}

\author{
Naseem Hyder Rajput ${ }^{1}$, Syed Muhammad Ahsan Bukhari ${ }^{1}$, Narmeen Noonari ${ }^{1}$, Dr. Ghulam Muhiuddin Solangi ${ }^{2}$, \\ Masood Ahmed Soomro ${ }^{1} \&$ Abdul Waheed Dahri ${ }^{1}$ \\ ${ }^{1}$ M.Phil Associates, Department of Education, Shaheed Benazir Bhutto University, Shaheed Benazirabad, \\ Pakistan \\ ${ }^{2}$ Assistant Professor, Department of Education, Shaheed Benazir Bhutto University, Shaheed Benazirabad, \\ Pakistan \\ Correspondence: Naseem Hyder Rajput, Department of Education, Shaheed Benazir Bhutto University, Shaheed \\ Benazirabad, Pakistan.
}

Received: April 11, 2020

Accepted: July 7, 2020

Online Published: July 9, 2020

doi:10.5539/mas.v14n8p23

URL: https://doi.org/10.5539/mas.v14n8p23

\begin{abstract}
Pakistan, in the last 10 years, has witnessed a fast and deep penetration of computers, internet, and android cell phones in the everyday lives of the teachers. The education process has yet to enjoy the full benefits of this technology despite the implementation of $3 \mathrm{~g} / 4 \mathrm{~g}$ technologies and a surge of android cell phones. Therefore, teachers being an integral and vital part of the education process need to be well aware of the importance and should be trained at incorporating ICT in their daily teaching processes. This survey-based descriptive study gauged the familiarity of High School Teachers with ICT and its level of incorporation in the teaching process at the secondary level. The population of this study was $617(\mathrm{~N}=617)$ High School Teachers belonging to 61 secondary schools of the district. About 245 teachers who participated in this study were randomly selected from 24 secondary schools. A self-developed questionnaire was distributed to these teachers. All the questionnaires were filled and returned. About 8 of these questionnaires were incomplete and therefore were deemed unusable. Therefore, only 237 questionnaires were used for data analysis. The findings of this study indicated that only $15 \%$ of the participants knew about ICT and its uses in the teaching process. Internet browsing, e-mailing and operating a CD Rom device as well-known aspects and simulations, problem-solving software, and graphics were some of the ICT aspects which the participants appeared to be familiar with. Findings about the level of incorporation in the teaching process revealed that computer labs were available in about $15 \%$ of the schools; about $55 \%$ of the participants owned android cell phones; $45 \%$ had self-access to the internet and these android phones were mostly used for communication with other teachers and parents. About $2 \%$ used ICT for teaching specific subjects; out of the $2 \%$ that used ICT for teaching, only $0.5 \%$ used it as an essential part of daily instruction. The results also show that $0.25 \%$ of participants were formally trained in ICT. ICT was mostly used for finding and accessing and downloading educational materials. Less frequently used of ICT included making lectures, drills, and practice, preparing lesson plans, and video lecturing.
\end{abstract}

Keywords: ICT, high school teachers, awareness, integration, secondary level

\section{Introduction}

\subsection{Background}

In this digital era, Information Communication Technology (ICT) has become an integral part of our daily lives. Today, ICT is so commonplace in our daily lives that even illiterates are found using android mobiles (Tirmizi et al, 2019). ICT has not only impacted the everyday lives of people of developed countries but has also impacted the lives of people belonging to developing countries like Pakistan. The impact of ICT on our daily lives is such great that it has approximately changed all forms \& functions of our lives. In education, the incorporation of ICT has transformed the teaching process from teacher-centered to student-centered. Now students can even learn the difficult concepts of science through simulation. These concepts were previously taught by the teachers and memorized by the students in classrooms. 
Cell phones, radio, TV, and the internet, etc. which all are included in ICT, are playing an important role in various fields of our daily lives including education. But, in Pakistan, the education process has yet to enjoy the full benefits of this technology (Zafar, Akram, \& Shakir, 2017); despite the implementation of $3 \mathrm{~g} / 4 \mathrm{~g}$ technologies and surge of android cell phones (Adnan, Yousaf, \& Gilani, 2019). With the availability of the massive amount of information in this digital era, the students and teachers both require knowing how to access $\&$ retrieve the information that is appropriate according to their needs.

In Pakistan, the first effort to include ICT in the education process was made when a chapter was included in the National Education Policy 1998-2008. This chapter focused mainly on preparing and training teachers regarding ICT with the purpose to enable them for their new role of teaching with ICT. This was followed by launching a valuable program named "Partners in Learning" (PiL) in 2004. This program was launched with the help of Microsoft Corporation. One of the major areas focused under this program was to set up a chain of personal computer laboratories in the teacher training institutes for the proper training of teachers in ICT. Education Sector Reform Assistance (ESRA) and Microsoft were collaborators in devising National Information and Communication Technology strategy in 2006. Under this strategy, ICT was introduced in teacher training institutes to improve the quality of teaching. In the National Education Policy 2009, very little importance was given to ICT with the reduction of the chapter on Information Technology (IT) to only lip service with no plan for its implementation as a proper subject like others. This policy focused on six actions. One of which was to use ICT to improve the quality of teaching with the introduction of ICT in teacher training institutions.

In the last 25 years or so ICT has acquired an important place in the education process of the world. Pakistan, in the last 10 years, has also witnessed a fast and deep penetration of computers, internet, and android cell phones in the everyday lives of the teachers (Rashid, 2018). Unfortunately, this fast penetration has not been observed in the teaching process. So, in Pakistan, the education process has yet to enjoy the full benefits of this technology despite the implementation of $3 \mathrm{~g} / 4 \mathrm{~g}$ technologies and surge of android cell phones. Therefore, teachers being an integral and vital part of the education process need to be well aware of the importance and should be trained at incorporating ICT in their daily teaching process.

\subsection{Significance of the Study}

Schools at the secondary level are the eventual feeder organizations for colleges in the city of Shaheed Benazirabad. A high-quality product of these schools will result in better intakes for colleges and the students as a result passing out will be additionally skillful and much improved in their academic performance to compete in this digital age. Because the government expends a significant segment of its finances on education, so, the anticipations are greater. Although over the few years the usage of ICT in our personal lives has been at a boost, usually it is deemed that ICT has not been integrated into our professional lives. Even in the case of application of ICT in education, full potential incorporation of ICT has yet to be materialized. Furthermore, the only smart portion of ICT that is being applied in the educational process is not uniform itself; the usage of (ICT) in the educational process is much more tilted towards science education-related subjects rather being associated with other subjects (Yelland, 2011). As this study assesses the familiarity of High School Teachers with ICT and its level of incorporation in the teaching process at the secondary level so it will help the authorities in ascertaining the actual level of incorporation of ICT solely in the teaching process. Further, this study will help the decision-makers to identify the training needs of the teachers at the secondary level which are currently engaged in using ICT in the teaching process. This research will also assist in the preparation of strategies regarding ICT training regarding the effective use of ICT in classrooms. This study is also significant in the sense that it will shed light on some of the important areas of ICT which are not utilized effectively by the teachers.

\subsection{Problem Statement}

Reviewed literature suggests that ICT can play several vital roles in education by changing the teaching and learning process. This study is aimed at assessing the familiarity of High School Teachers with ICT and its incorporation in the teaching process. In this ever-changing and digital world, education is much more than a source of imparting knowledge, making developments, and eliminating poverty. Today education is also important for knowledge-based economies. This study will help the authorities in ascertaining the actual level of incorporation of ICT in the teaching process; the decision-makers to identify the training needs of the teachers; assist in the preparation of strategies regarding ICT training about the effective use of ICT in classrooms; will shed light on some of the important areas of ICT which are not utilized by the teachers.

\subsection{Objectives}

The incorporation of ICT in the educational process is a multidimensional process. "Teachers" are an integral part of this multidimensional process for its successful incorporation. So, this study aims at assessing the 
familiarity of the secondary level teachers with ICT and ascertains its level of incorporation in the teaching process. The following were the objectives of the study:

- To assess the familiarity level of High School Teachers with Information Communication Technology (ICT)

- To ascertain the level of incorporation of ICT in the teaching process at the secondary level

\section{Reviewed Literature}

Information and communication technology is defined as a set of tools that can help provide the right people with the right information at the right time (Hussain \& Safdar, 2008). Now a day, ICT is deemed necessary for almost every activity. Policymakers have consensus among them that the support of ICT is needed for various activities whether these are commercial, developmental, or governmental (Dutta \& Das, 2011). Today's children are digital natives. They should know how to access and take out the required information from the massive amount of information that is lying under his fingertips in the form of the Internet. Therefore, for those digital natives, literacy in ICT is considered a requirement (Shah, 2016).

The benefits of the application of ICT are far-reaching. The integration of ICT has transformed our world into a global village. Previously, inaccessible communities have now become accessible because of this ICT (Jafri, Soomro \& Khan, 2011). It employs that ICT can be used as an instrument for globalization (Nair \& Hindle, 2013).

ICT offers definite chances to encourage growth and enhance modernization in every local context, thus facilitating persons and organizations to work together more prolifically with the economy of the world (Carayannis, 2014). ICT has moved onward and penetrated quickly in the everyday lives of the people in advanced countries. The picture is not pleasing in the case of developing countries like Pakistan. In these countries, the teachers are lacking behind because of various hurdles. Nevertheless, the teachers of all the countries have had to build up novel expertise to keep them abreast of time.

In this new millennium, ICT and development are integral to one another; doors to education are opened by the ICT while in turn education opens doors to development (Sahito \& Vaisanen, 2017). ICT can help teachers in maintaining their jobs through professional development (Carlson \& Gadio, 2002). Teachers can also enhance their skills \& can link them to their global counterparts (Jung, 2005).

Perspectives of educators towards the usage of ICT \& their readiness are important because the only supply of ICT apparatus \& basic structure shall not be helpful (Zhao \& Cziko, 2001). A variety of aspects of educators like, lack of competency \& self-belief, unconstructive approaches and institutional/managerial aspects such as shortage of time, well-organized guidance, neighboring technological help \& management are significant among inherent aspects as obstructions in the implementation of good ICT policies (Almalki \& Williams, 2012). Inappropriate planning, scarcity of financing \& local traditions are chief extraneous aspects obstructing ICT in classroom instructions.

Teachers belonging to various regions of the world are fully skilled in using ICT \& they are extracting full-scale benefits of ICT. Teachers belonging to approximately all the countries of the Asia Pacific region are being trained in the use of ICT to varying extents and scales (Bangkok, UNESCO, 2003). The incorporation of ICT in the teaching process cannot only keep the teachers up-to-date with the content knowledge but it will also improve the academic performance of the students. However, this incorporation should be carried out after a thorough understanding of ICT principles and its concept. As the developments in ICT are drastic, so their implementations should be considered at the time of ICT curricula design (Voogt \& Pelgrum, 2005).

Only a small number of learners are fond of the conventional method of classroom education \& mass students favor studying with inventive methods (Oguzor, 2011). Conventional classroom educational procedures can ignore the necessary aspects of the process of education. If used correctly, ICT is established to be a wonderful reserve for teaching but simultaneously he also confesses that even though how efficient computers are, they can never put back educators in the classroom.

Information and communication technologies can have excellent impacts upon the procedure of education as it offers several alternatives both meant for educators and students (Nikolić et al, 2019). Not only the employment of the equipment in the classroom, acquiring software, \& educators training, but the efficient employment of ICT has lots to do with educators' perspectives towards using ICT in the teaching process (Hasala \& Kelly, 2020). There is no considerable dissimilarity in the usage of ICT when used in the classroom scenario, with the clues that a slightly smaller leaning among male educators takes place than female educators (Kinnari-Korpela, 2019); there is no gender and age-wise difference about the purpose for using smart mobile devices (Papadakis, 2018). When it comes to the use of mobile phones in the education process, there are thousands of educational apps 
available today, and choosing the most appropriate educational app for children is difficult and problematic for both teachers and educators (Papadakis \& Kalogiannakis, 2017). There are thousands of tools ICT tools that teachers can use to support the education process. According to (Kalogiannakis \& Papadakis, 2019), the attitudes of pre-service teachers towards the effectiveness of the cell phone learning in the teaching process strongly influence their intention to implement cell phone learning followed equally by perceived ease of use. According to Kalogiannakis \& Papadakis (2020), there is a need to develop teaching and learning processes that go afar only spread of the technical knowledge prerequisite to use cell phone technologies for educational purposes; they should be focused rather on awaking students about the educational profits that the incorporation of cell phone technologies can add to formal education.

ICT literacy is the requirement of time for the secondary teachers for their success because ICT skills improve the teaching skills of these teachers both theoretically and practically. As a result of these benefits, there is an ever-growing need for ICT to incorporate it into secondary teachers' education so that secondary teachers can transfer their positive effects on their teaching and students' learning.

This study adds to the body of knowledge by the fact that no previously conducted study explored the extent of ICT incorporation at the secondary level in District Shaheed Benazirabad.

\section{Methodology}

\subsection{Study Design}

The purpose of the study was to assess the familiarity of High School Teachers with ICT and the level of its incorporation in the teaching process at the secondary level. To achieve these objectives a survey was conducted in secondary schools of the District. This survey-based study is quantitative by method and descriptive by purpose. A two-part, self-developed questionnaire tool was used to collect the data survey data from the participants. To collect the survey data from participants, a two-part, self-developed questionnaire tool was used.

\subsection{Population and Sample}

The population consisted of $617(\mathrm{~N}=617)$ male High School Teachers belonging to 61 secondary schools of District Shaheed Benazirabad. There are separate schools for boys and girls in our country that's why only male teachers teaching in boys' schools were selected. Using information obtained from District Education Office Shaheed Benazirabad, each secondary school within the district was assigned a number. Out of a total of 61 secondary schools, 24 secondary schools from the district were identified and randomly selected. The Head Teacher of every chosen school was spoken to using cell phones \& their permission was sought to contribute to the completion of the survey. Head Teachers at random spoke to $245(n=245)$ male High School Teachers who educate in their schools and acquired their contribution to the completion of this survey-based study.

\subsection{Instrumentation}

The tool used for this survey-based descriptive study to collect data was comprised of a questionnaire. Tool comprised of two parts with the first part containing (17) items about the familiarity of teachers with ICT and the second part containing (22) items regarding the level of incorporation of ICT in the teaching process.

The instrument was pretested in a pilot study. A group of 20 teachers completed the survey with a gap of 8 weeks to determine the reliability of scores over time. The score of each item was correlated and the resulting coefficient was calculated to be .87 which indicated the instrument was reliable.

\subsection{Data Collection}

Using data and contact details of the headteachers obtained from the District Education Office Shaheed Benazirabad, the researchers contacted the headteachers through cell phones and explained to them about the proposed study to seek their consent. Later the headteachers were requested to seek the consent of teachers working under their supervision that were randomly selected and shown interest to participate in the study. Once the process of seeking permission was over then the researchers started visiting the participating schools. In each visited school the teachers working there were requested to gather in a classroom and the researchers explained to them the purpose of the study. Then the researchers explained to the participants how to complete the survey as not a single participant had participated in any kind of survey previously.

The survey tool was distributed to all the participants at the same time. The total number of survey questionnaires distributed amongst the participating High School Teachers in 24 schools was 245. But 8 completed survey questionnaires were unusable because of incomplete information and ultimately were not included in the analysis leaving $96.73 \%$ of the distributed questionnaires. This resulted in dropping down the 
total number of survey questionnaires for data analysis to 237 . The duration to complete the survey tool was approximately half an hour. The data collection lasted for one month.

\subsection{Data Analysis}

The collected data was analyzed using SPSS Descriptive Stats command to calculate the percentages of the responses.

\section{Results}

Table 1. Demographic Information

\begin{tabular}{|c|c|c|c|c|c|c|c|}
\hline $\begin{array}{c}\text { No. of } \\
\text { Participating } \\
\text { Schools }\end{array}$ & $\begin{array}{c}\text { No. of } \\
\text { Participants }\end{array}$ & Gender & $\begin{array}{c}\text { Average } \\
\text { Age in } \\
\text { Years }\end{array}$ & $\begin{array}{l}\text { Average } \\
\text { Teaching } \\
\text { Experience } \\
\text { in Years }\end{array}$ & $\begin{array}{c}\text { Current } \\
\text { Placement }\end{array}$ & $\begin{array}{c}\text { Academic } \\
\text { Qualifications }\end{array}$ & $\begin{array}{l}\text { Professional } \\
\text { Qualifications }\end{array}$ \\
\hline & & & & & & $\begin{array}{l}\text { Master of } \\
\text { Science } \\
(2.85 \%)\end{array}$ & M.Ed. (17.14\%) \\
\hline \multirow[t]{3}{*}{24} & 245 & $\begin{array}{c}\text { All } \\
\text { Male }\end{array}$ & 49 Years & 26.5 years & $9^{\text {th }} \& 10^{\text {th }}$ & $\begin{array}{c}\text { Bachelor of } \\
\text { Science } \\
(7.77 \%)\end{array}$ & B.Ed. $(57.14 \%)$ \\
\hline & & & & & & $\begin{array}{c}\text { Master of Arts } \\
62.04 \%\end{array}$ & C.T $(11.02 \%)$ \\
\hline & & & & & & $\begin{array}{c}\text { Bachelor of } \\
\text { Arts }(27.34 \%)\end{array}$ & P.T.C (11.8\%) \\
\hline
\end{tabular}

According to results presented in Table1, High School Teachers are generally good in terms of academic and professional qualifications. Over sixty-four percent possessed Master level degrees and approximately $36 \%$ held Bachelor level degrees. More than ninety-seven percent of High School Teachers held professional teaching qualifications (PTC, CT, B.Ed., and M.Ed.).

The first objective of the study was to assess the familiarity of High School Teachers with Information Communication Technology (ICT). The finding of the study about this first objective is presented in Table 2.

Table 2. Familiarity with ICT

\begin{tabular}{ccc}
\hline Sr. No. & Aspect of ICT & Percentage \\
\hline 1 & Awareness about ICT & $15 \%$ \\
2 & Internet Browsing & $65 \%$ \\
3 & E-Mailing & $35 \%$ \\
4 & Operating a CD Rom Device & $30 \%$ \\
5 & Operating an Optical Scanner & $17 \%$ \\
6 & knowledge about ICT & $15 \%$ \\
7 & Word-Processing & $10 \%$ \\
8 & Presentation Tools & $8 \%$ \\
9 & Multimedia Presentations & $7 \%$ \\
10 & Statistical Tools & $5 \%$ \\
11 & Tutorials & $5 \%$ \\
12 & Graphics & $3 \%$ \\
13 & Problem Solving Software & $2 \%$ \\
14 & Operating a Projection Device through Computer & $2 \%$ \\
15 & Database Management & $1 \%$ \\
16 & Math Related Software & $1 \%$ \\
17 & Simulations & $1 \%$ \\
\hline
\end{tabular}


According to data analysis of items about the first objective shown in table 2, internet browsing turned out to be the most famous item of the ICT that is known by the $65 \%$ of the participants. It is followed by e-mailing which is the second most known aspect of the ICT which stands at $35 \%$.

Images or text on paper can be converted into digital formats that can be used by the computers as electronic resources. These electronic versions can include reports, documents, forms, and administration data. Scanners can also be used for photocopying, capturing text, and sharing the material that is available in the form of only a single file. When inquired from participants about familiarity with optical scanners, responses indicated that $17 \%$ of the participants knew about optical scanners.

ICT that has revolutionized the teaching process in developed countries still is an undiscovered treasure in developing countries like Pakistan. When asked about ICT as a whole $15 \%$ of participants expressed that they know about ICT and its uses in the teaching process.

Traditional typewriters have been replaced by the word processing tools decades ago. One of the precious parts of technology now teachers can use in teaching processes are word processors. By using word processors teachers cannot only process texts but also perform spell checking. Assignments can be spared from being misplaced or lost. Another great part of the technology that was originally used in businesses is presentation tools. Presentation tools are now also being employed in education. Presentation tools can help students to shift from just listening to seeing. Teachers can achieve greater focus of attention from students in class using presentation tools. Participants' responses indicated that the percentage of familiarity of participants with word processing and presentation tools was $10 \%$ and $8 \%$ respectively.

The use of multimedia presentation tools in education is on a rise in recent years as it plays an irrefutable part in education. Teachers are always in search of methods that can increase students' interest in the teaching process \& motivate them. Multimedia presentation is one of such methods. These methods not only make learning more effective but are also more attractive than traditional teaching methods. In addressing the familiarity with multimedia presentations, $7 \%$ of the participants responded that they are known to multimedia presentations.

Two essential parts of teaching and learning are measurement $\&$ evaluation. The familiarity with statistical tools helps teachers in measurement and evaluation in many ways. It helps teachers in enabling them to summarize results in a meaningful way, also help teachers in concluding. These further help teachers in predicting future performance of students. When asked participants whether or not they are familiar with statistical tools. Responses reveal that $5 \%$ of the participants are familiar with statistical tools.

Teaching through tutorials has received very much importance in recent days. It is a form of remedial teaching which can either be individualized or given in groups. The goal of this form of remedial teaching is to increase the cognitive $\&$ academic abilities of the students who are poor at these abilities. Responses show that $5 \%$ of the participants know about tutorials.

Although images are not always better than words yet principle called "picture superiority effect" has persuaded many that using effective images can enhance learning. Basis of the principle is the theory that memory for pictures is better than for their word counterparts. The study revealed that graphics enjoyed a $3 \%$ familiarity of the participants.

Problem-solving software focuses on the skills and approaches of the students especially needed to enhance problem-solving skills. Through strengthening the problem-solving skills of the students, the purpose of observing, sequencing, analyzing, inferring, predicting outcomes, making analogies can be achieved. Problem-solving software and operating a projection device through the computer were the second least known aspects of the ICT with both standing at $2 \%$.

Abstract and cumulative nature of Math has made it a difficult subject inherently. Because of such natures, strong foundations are required of the students. New things cannot be learned without having their previous knowledge. Math-related software permits more control of the students over problem-solving and interpretation $\&$ can also support the development of logical, mathematical arguments of the students. Record-keeping using computers allows users to store and retrieve information from an organized filing system. Students can be engaged in deep learning using simulations as compared to using traditional methods that empower students with surface learning only because of "memorization". When queried regarding the familiarity with Math related software, database management, and simulations, responses indicated that these were the least known aspects of the ICT with all three standing at $1 \%$.

The second objective was to ascertain the level of incorporation of ICT in the teaching process at the secondary level. The findings of this objective are shown in Table 3. 
Table 3. Incorporation of ICT in Teaching Process

\begin{tabular}{|c|c|c|}
\hline Sr.No. & Aspect of IC & Percentage \\
\hline 1 & Possession of Android Cell Phones & $55 \%$ \\
\hline 2 & Self-access to internet & $45 \%$ \\
\hline 3 & Communicating with other teachers & $35 \%$ \\
\hline 4 & Availability of Computer labs in school & $15 \%$ \\
\hline 5 & Communicating with parents & $15 \%$ \\
\hline 6 & Downloading teaching materials & $3 \%$ \\
\hline 7 & Finding/accessing educational materials & $3 \%$ \\
\hline 8 & Monitoring & $3 \%$ \\
\hline 9 & Record keeping & $2 \%$ \\
\hline 10 & Teaching for specific subjects & $2 \%$ \\
\hline 11 & Preparing notes & $2 \%$ \\
\hline 12 & Preparing test papers & $1.5 \%$ \\
\hline 13 & Preparing Reports & $1.5 \%$ \\
\hline 14 & Making lectures & $1 \%$ \\
\hline 15 & Preparing Lesson Plans & $1 \%$ \\
\hline 16 & Communicating with students (Homework, Testing) & $1 \%$ \\
\hline 17 & Preparing Test/Quiz & $1 \%$ \\
\hline 18 & Drill and practice & $1 \%$ \\
\hline 19 & Video lecturing & $0.75 \%$ \\
\hline 20 & Use as an important part of daily instruction & $0.5 \%$ \\
\hline 21 & Have Acquired ICT related training & $0.25 \%$ \\
\hline 22 & Institutional access to internet & $0.25 \%$ \\
\hline
\end{tabular}

Data analysis about the second objective, shown in table 3, suggests that more than half (55\%) of the participants owned android cell phones with $45 \%$ having access to the internet at their expenses.

Teachers' perceptions of the provision of computer labs provided by the government indicated that $15 \%$ of the participants had computer labs in their schools with less than one percent $(0.25 \%)$ having access to the internet through their institution.

When it comes to the incorporation of ICT in the teaching process, $35 \%$ of the participants said that they use ICT for communicating with the other teachers of their schools, and $15 \%$ use ICT for communicating with the parents of the students.

When responding to the item regarding the finding, accessing, and downloading the educational materials, $3 \%$ of the respondents said that they use ICT for finding, accessing, and downloading the educational materials.

$2 \%$ responded that they use ICT for record-keeping, preparing notes, and for the teaching of specific subjects. ICT was used by $1.5 \%$ of the respondents to prepare test papers and test reports.

Only 1 in a hundred (1\%) of the respondents used ICT for making lectures, drill and practice, preparing lesson plans, communicating with students (for Homework and Testing), and for preparing the tests and quizzes. Video lecturing was used by $0.75 \%$ of the respondents.

Responding to the item addressing whether they considered ICT as an essential part of their instruction, half percent $(0.5 \%)$ considered ICT as an essential part of their instruction.

When asked whether or not they are formally trained in the use of ICT, only $0.25 \%$ of the respondents said that they are formally trained in the use of ICT. 


\section{Discussions}

It is now a fact that ICT has demonstrated tremendous benefits in every field of life where it has been utilized (Bannister \& Connolly, 2020). It can be used to improve teaching and learning; its content is dynamic, interactive, and engaging. Individualized instruction can enjoy its full potential opportunities (Yusuf \& Onasanya, 2004).

Although the full potential incorporation of ICT in the teaching process and its associated benefits is evident in the case of developed countries yet the developing countries like Pakistan are even still not on track of its incorporation in the teaching process due to various reasons and barriers. In the last 15 years, Pakistan has witnessed a very fast penetration of ICT in the personal lives of teachers and students but the speed of this penetration in the teaching process has not been witnessed. Awareness of teachers towards ICT and effectiveness of its incorporation in the teaching process can play a very supportive and vital role in the use of ICT in classrooms in general \& teaching process in special. Because the present generation of students is digital native so they are often found employing ICT in their daily lives in the form of cell phones and other various devices. This status of being digital natives has also been felt by the teachers under whom supervision these digital natives undergo the process of education. This has resulted in the application of ICT in their personal lives but not in professional lives. Teachers have always been accepted as an important player in improving the teaching process in schools to achieve their goals on a large scale. Because today's teacher belongs to the digital age so he is required of the possession of skills and expertise that were not required by the teachers of the previous age to keep them abreast of times. Today an ICT literate teacher is required by all kinds of educational institutes for them to compete well in this digital age.

The purpose of the study was to assess the familiarity of High School Teachers with ICT and the level of its incorporation in the teaching process.

The findings of this study reveal that, even in this digital age with more than half (55\%) of the participants in possession of android cell phones and having a connection to the internet, $85 \%$ of the participants even do not know about this very beneficial technology in the form of ICT. These findings add to the results of Shakir, Akhtar \& Khan (2016). In that study, the researchers concluded that over fifty percent of secondary school teachers did not know about the constructive use of information and communication technology. According to Afshari et al (2009), and effective learning environment can be enhanced by using information and communication technology.

Ten national professional standards for teachers were developed by Pakistan. The seventh standard for teachers is related to the attitude, required skills, and applications of ICTs by teachers professionally (Khan \& Islam, 2015). These standards have been developed to determine the skills and attributes which are deemed important for teachers in the $21^{\text {st }}$ century. These findings reveal that the teachers are not up to the seventh national professional standard for teachers as the majority of the participants (85\%) did not know about ICTs and only $2 \%$ of the participants used ICTs in their professional work.

However, perspectives about using ICT in teaching specific subjects revealed only $2 \%$ of the respondents employed ICT in the teaching process of specific subjects while out of this $2 \%$ only $0.5 \%$ used ICT as an essential part of their daily instruction. These results support the results of Khan and Islam (2015); Shakir, Akhtar \& Khan (2016), that the majority of school teachers do not use ICTs. According to Jogezai, Ismail \& Baloch (2018), reasons for the low level of awareness of ICTs among teachers include possibilities of increasing workload, informational concerns, low knowledge of potential benefits associated with the integration of ICTs, management of time and resources.

There is a substantial gap between familiarity with ICT (15\%) and its incorporation in the teaching process as an essential part of daily instruction ( $0.5 \%)$. This gap, if abridged either via formal pieces of training on ICT or via workshops highlighting the importance \& benefits of using ICT in the teaching process, will not only transform the profession of teaching from static to dynamic but will also improve the achievement on educational outcomes. ICT integration as a viable initiative for improving the overall quality of education in the country. The integration of ICTs in teaching and learning process can improve the overall quality of education in Pakistan (Jogezai, Ismail \& Baloch, 2018)

Teachers and students are key players in the integration of ICTs in teaching and learning processes. According to Hismanoglu (2012), pieces of training are remarkable in ICT integration. According to Fullan (2007), effective incorporation of ICTs depends on teachers' understanding and magnitude of concern about it.it reflects that a low level of awareness about ICTs is a barrier in the successful integration of ICTs in the teaching and learning process in Pakistan. Teachers' awareness level needs to be improved and their concerns require to be addressed 
in this regard. Teachers' concerns are significant in determining the adoption and implementation of educational innovations, (Puteh, Salam, \& Jusoff, 2011). According to Puteh, Salam, \& Jusoff (2011), any innovation in education needs a significant amount of attention being paid to teachers' apprehensions. successful adoption and implementation of such innovations call for increment in the awareness level of teachers.so to uplift the educational quality and standards through implementing the innovation of ICTs in the teaching and learning process, teachers are required to increase the level of their awareness about it.

Cheap internet connections and android cell phones are already available with more than half of the participants and participants are spending enough time on browsing. The only thing required is to persuade the participants to apply ICT using cell phones in the teaching process. Using Android phones in learning environments promotes self-confidence and interaction with the teacher and peers; It also helps a teacher to provide individual feedback to the students, improving students' engagement in learning tasks (Rashid, 2017).

Formal pieces of training in the use of ICT, which are neither provided by the government nor acquired by the participants at their own, can be offered to the teachers to illuminate them the full potential benefits of ICT. Unavailability of pieces of training is a barrier to the integration of this novel technology in the teaching and learning process. According to Dawes (1999) cited in Mumtaz (2000), teachers are resistant to change due to lack of access to ICTs, inadequate familiarization of teachers with ICTs, insufficient administrative and technical support, the deficiency of training rendered to instructors in ICT integration, (Rosen \& Weil, 1995, p.30).

Once the teachers started applying ICT in the teaching process, then the majority of respondents (55\%) who own android phones will be able to utilize these devices as an ICT tool in the teaching process. This will reduce the financial burden on the government to provide heavy infrastructure in the form of computer labs in schools. it will also help in enhancing the educational standards of the educational institutions.

Interestingly, findings further reveal that enough number of respondents, despite having self-access to the internet, never used the internet for online tools of tests. Online sources are only used for teaching and learning. These are not used for collecting teaching information but widely used for communicating among themselves and with the parents of their students.

ICT tools can help educators in the preparation of lectures but the educators are not willing to use computers as teaching aids inside their classroom. Furthermore, educators are fully trained in the use of android phones and internet browsing (Ali, 2015); but not formally trained how they can incorporate ICT instruments in the teaching process so that it can be made easier to understand (Hussain et al, 2010). This important tool of ICT available in the form of android cell phones with an internet connection is mostly used for personal assignments with $65 \%$ using for internet browsing and 35\% using for communication with other teachers.

\section{Recommendations}

Based on the findings of this study it is recommended that:

i. Computers should be incorporated into classroom education,

ii. Educators should be persuaded to make use full use of the communication technologies (internet) so that they can uphold a close link with the parents of their students for usual feedback.

iii. Computers should be used for the arrangement of reinforcements/enrichments of the material taught within the classroom \& for the students who cannot be present at the classes for some serious reasons.

iv. The use of online evaluation instruments, simulation, programming of computers, and the designing of web pages should be incorporated in the guidance material of the teachers so that they can turn out to be independent in creating readymade resolutions for their explicit teaching requirements.

v. The administration of educational organizations has to recognize that the mere supply of equipment \& the internet is not enough if the supply of good quality software is not guaranteed.

vi. It is believed that computers can be used for the education of almost all kinds of the subjects \& because educators have fixed duration of classes, therefore, support staff should be deputed for protection of the equipment and making them prepared before the start of the classes so that they can be used during classes without wasting time.

\section{Limitations}

This study has several limitations. This study did not include the female High School Teachers of the district. It also did not include the teaching staff of secondary schools other than High School Teachers like Junior School Teachers, Oriental Teachers, Commerce Teachers, Work Shop Instructors, Agricultural Instructors, and Physical 
Training Instructors. Further, it included only the public sector High School Teachers but not the teachers of private schools of secondary level which are working in this district.

\section{Conclusion}

The incorporation of ICT in the teaching process is a potential way to face the challenges of globalization in this digital world. Through the incorporation of ICT, teachers can equip them with the latest knowledge of their field and keep them abreast of time in this global village of teaching. The incorporation of ICT in education is a full-scale process in which the latest technologies are applied to the curriculum for improving teaching and learning. Cell phones, radio, TV, and internet, etc. are included in ICT. This study was conducted to assess the familiarity of High School Teachers with ICT and its incorporation in the teaching process in District Shaheed Benazirabad. It has been concluded from the findings of the study that the majority of the High School Teachers, despite having possession of android cell phones and connect to the internet, are neither familiar nor formally trained in the use of ICT in the teaching process. Further, the majority of the High School Teachers are also not incorporating ICT in their teaching process.

\section{References}

Adnan, M., Yousaf, Z. \& Gilani, A. H. (2019). E-Learning with Digital Media and Human Development: The Way Forward for Pakistan. Journal of Educational Research, (1027-9776), 22(2).

Afshari, M., Bakar, K. A., Luan, W. S., Samah, B. A. \& Fooi, F. S. (2009). Factors affecting teachers' use of information and communication technology. International journal of instruction, 2(1).

Ali, M. M. (2015). Integration of ICT in ELT Class Rooms: Teachers' Perceptive. Putaj Humanities \& Social Sciences, 22(2).

Almalki, G. \& Williams, N. (2012). A strategy to improve the usage of ICT in the Kingdom of Saudi Arabia primary school. International Journal of Advanced Computer Science \& Application, 3. https://doi.org/10.14569/IJACSA.2012.031007.

Bangkok, U. N. E. S. C. O. (2003). Developing and Using Indicators of ICT Use in Education. Compiled by UNESCO Asia and Pacific Regional Bureau for Education, Bangkok, and Southeast Asian Ministers of Education Organization Regional Centre for Educational Innovation and Technology, Metro Manila, Philippines.

Bannister, F. \& Connolly, R. (2020). The future ain't what it used to be: Forecasting the impact of ICT on the $\begin{array}{llll}\text { public } & \text { sphere. Government } & \text { Information } & \text { Quarterly, 37(1), }\end{array}$ https://doi.org/10.1016/j.giq.2019.101410.

Canton, J. R. (2015). Strength in numbers: An exploration of female attitudes towards mathematics in elementary schools. Nipissing University (Canada).

Carayannis, E. G. (2014). E-Development and Knowledge Economy: The Role of ICT and SME Incubation. In Cyber-Development, Cyber-Democracy and Cyber-Defense (pp. 23-90). Springer, New York, NY. https://doi.org/10.1007/978-1-4939-1028-1_2.

Carlson, S. \& Gadio, C. T. (2002). Teacher professional development in the use of technology. Technologies for education, 118-132.

Dutta, S. \& Das, S. (2011). ICT and Rural Infrastructure: Cases from Indian Rural Sector. IUP Journal of Infrastructure, 9(4).

Fullan, M. (2007). The new meaning of educational change. New York: Teachers College Press.

Gatautis, R. (2008). The impact of ICT on public and private sectors in Lithuania. Inžinerine ekonomika, (4), $18-28$.

Hasala, V. \& Kelly, R. (2020). The perception and use of ICT in education by primary school teachers in Finland and Japan (Master's thesis). Faculty of Information Technology, University of Jyväskylä, Jyväskylä, FINLAND. Retrieved on June 24, 2020 from http://urn.fi/URN:NBN:fi:jyu-202006094044.

Hismanoglu, M. (2012). Prospective EFL teachers' perceptions of ICT integration: A study of distance higher education in Turkey. Journal of Educational Technology \& Society, 15(1), 185-196.

Hussain, I. \& Safdar, M. (2008). Note for Editor: Role of Information Technologies in Teaching Learning Process: Perception of The Faculty. Turkish Online Journal of Distance Education, 9(2), 46-56. 
Hussain, M. A., Niwaz, A., Zaman, A., Dahar, M. A. \& Akhtar, M. (2010). Technology based learning environment and student achievement in English as a foreign language in Pakistan. Journal of World Academy of Science, Engineering, and Technology, 61, 129-133.

Jafri, I. H., Soomro, M. S. \& Khan, R. A. (2011). ICT in distance education: improving literacy in the province of Sindh Pakistan. The Sindh University Journal of Education-SUJE, 40.

Jogezai, N. A., Ismail, S. A. M. M. \& Baloch, F. A. (2018). Secondary School Teachers' Concerns about ICT Integration: Perspectives from a Developing Part of the Globe. EURASIA Journal of Mathematics, Science and Technology Education, 14(12), em1620. https://doi.org/10.29333/ejmste/95124.

Jung, I. (2005). ICT-pedagogy integration in teacher training: Application cases worldwide. Journal of Educational Technology \& Society, 8(2), 94-101.

Kalogiannakis, M. \& Papadakis, S. (2019). Evaluating pre-service kindergarten teachers' intention to adopt and use tablets into teaching practice for natural sciences. International Journal of Mobile Learning and Organisation, 13(1), 113-127. https://doi.org/10.1504/IJMLO.2019.096479.

Kalogiannakis, M. \& Papadakis, S. (2020). The Use of Developmentally Mobile Applications for Preparing Pre-Service Teachers to Promote STEM Activities in Preschool Classrooms. In Mobile Learning Applications in Early Childhood Education (pp. 82-100). IGI Global. https://doi.org/10.4018/978-1-7998-1486-3.ch005.

Khan, R. \& Islam, S. U. (2015). An evaluation of national professional standards of public sector school teachers at primary level in district Peshawar. The Dialogue, 10(4), 365-376.

Kinnari-Korpela, H. (2019). Enhancing Learning in Engineering Mathematics Education: Utilising Educational Technology and Promoting Active Learning.

Mikre, F. (2011). The roles of information communication technologies in education: Review article with emphasis to the computer and internet. Ethiopian Journal of Education and Sciences, 6(2), 109-126.

Mumtaz, S. (2000). Factors affecting teachers' use of Information and Communications Technology: a review of the literature. Journal of Information Technology for Teacher Education, 9(3), 319-341. https://doi.org/10.1080/14759390000200096.

Nair, G. \& Hindle, R. (2013). Use of ICT in Education. International Journal of Information Communication $\begin{array}{llll}\text { Technologies } \quad \text { and Human } & \text { 10-19. }\end{array}$ https://doi.org/10.4018/ijicthd.2013100102.

Nikolić, V., Petković, D., Denić, N., Milovančević, M. \& Gavrilović, S. (2019). Appraisal and review of e-learning and ICT systems in the teaching process. Physica A: Statistical Mechanics and its Applications, 513, 456-464. https://doi.org/10.1016/j.physa.2018.09.003.

Oguzor, N. S. (2011). Computer usage as instructional resources for vocational training in Nigeria. Contemporary Educational Technology, 2(3), 188-199. https://doi.org/10.30935/cedtech/6053

Papadakis, S. (2018). Evaluating pre-service teachers' acceptance of mobile devices with regards to their age and gender: a case study in Greece. International Journal of Mobile Learning and Organisation, 12(4), 336-352. https://doi.org/10.1504/IJMLO.2018.095130.

Papadakis, S. \& Kalogiannakis, M. (2017). Mobile educational applications for children: what educators and parents need to know? International Journal of Mobile Learning and Organisation, 11(3), 256-277. https://doi.org/10.1504/IJMLO.2017.085338.

Puteh, S. N., Salam, K. A. A. \& Jusoff, K. (2011). Using CBAM to evaluate teachers' concerns in science literacy for human capital development at the preschool. Learning Innovation and Intervention for Diverse Learners, 14, 8187.

Rashid, S. (2018). The effect of training in Mobile Assisted Language Learning on attitude, beliefs and practices of tertiary students in Pakistan (Doctoral Thesis), University of Canterbury, Christchurch, New Zealand. Retrieved on June 24, 2020 from http://hdl.handle.net/10092/16622.

Rashid, S., Cunningham, U. \& Watson, K. (2017). Task-based language teaching with smartphones: A case study in Pakistan. Teachers and Curriculum, 17(2), 33-40. https://doi.org/10.15663/tandc.v17i2.167. 
Rosen, L. D. \& Weil, M. M. (1995). Computer Availability, Computer Experience and Technophobia among Public School Teachers'. Computers in Human Behavior, 11(1). Retrieved March 22, 2020 from http://www.sciencedirect.com/science/journal/07 475632.

Sahito, Z. \& Vaisanen, P. (2017). Effect of ICT Skills on the Job Satisfaction of Teacher Educators: Evidence from the Universities of the Sindh Province of Pakistan. International journal of higher education, 6(4), 122-136. https://doi.org/10.5430/ijhe.v6n4p122.

Shah, A. A. (2016). Implementation of ICT in Secondary Education: A Case Study of District Ghotki, Sindh. NICE Research Journal, 60-73.

Shakir, M., Akhtar, A. \& Khan, H. M. A. (2016). Analysis of Effective Communication and Proficient Use of Information and Communication Technologies: A Case Study of Secondary School Teachers of Pakistan. Pakistan Journal of Social Sciences (PJSS), 36(2).

Sife, A., Lwoga, E. \& Sanga, C. (2007). New technologies for teaching and learning: Challenges for higher learning institutions in developing countries. International journal of education and development using ICT, 3(2), 57-67.

Tirmizi, S. A. U., Iftikhar, Y., Ali, S., Ehsan, A., Ehsan, A. \& Shahid, S. (2019, September). Ustaad: A Mobile Platform for Teaching Illiterates. In IFIP Conference on Human-Computer Interaction (pp. 788-796). Springer, Cham. https://doi.org/10.1007/978-3-030-29384-0_47.

Voogt, J. \& Pelgrum, H. (2005). ICT and curriculum change. Human Technology: An Interdisciplinary Journal on Humans in ICT Environments. https://doi.org/10.17011/ht/urn.2005356.

Yelland, N. (2011). Knowledge building with ICT in the early years of schooling. Нe Kupu, 2(5), 33-44.

Yusuf, M. \& Onasanya, S. (2004). Information and communication technology (ICT) and teaching in tertiary institutions. Teaching in Tertiary Institutions, 67-76.

Zafar, J. M., Akram, M. \& Shakir, M. (2017). Integrating ICT in teacher education programs: learning, motivation and knowledge dissemination of prospective teachers. Journal of Quality and Technology Management, 14(II), 174-185.

Zhao, Y. \& Cziko, G. A. (2001). Teacher adoption of technology: A perceptual control theory perspective. Journal of technology and teacher education, 9(1), 5-30.

\section{Copyrights}

Copyright for this article is retained by the author(s), with first publication rights granted to the journal.

This is an open-access article distributed under the terms and conditions of the Creative Commons Attribution license (http://creativecommons.org/licenses/by/3.0/). 